\title{
How Impact Exchange Rate to Processed Food Industry in Indonesia
}

\author{
Indra Suhendra* \\ Department of Economics Development \\ University of Sultan Ageng Tirtayasa \\ Jalan Raya Jakarta km 4, Seang 42124, Indonesia \\ *indras_23@untirta.ac.id
}

\author{
Navik Istikomah \\ Department of Economics Education \\ Universitas Pendidikan Indonesia \\ J1. Dr. Setiabudhi No. 229, Bandung 40154, Indonesia \\ Navik.istikomah@upi.edu
}

\begin{abstract}
This Paper employs a series method to measure exchange rate to the price of food industries. We use Purchasing Power Parity as our theoretical basis to demonstrate exchange rate fluctuation. The regression model, derived from the theoretical model, gives the statistically robust result to show that years 2006 to 2016. The result shows that the exchange rate influent on WPI and CPI of food industries. This study indicates that Industry of processed and preserved meat, fish and food oil; Industry of milk and dairy products; Industry of ground grains and nuts and fodder, and Other Food Industries sensitive to the fluctuation of exchange rate.
\end{abstract}

Keywords - processed food industry, exchange rate

\section{INTRODUCTION}

The food and beverage industry is one of the fastestgrowing industries in Indonesia. Various types of food and beverages with an attractive appearance advance to be created while the order to increase the aesthetic value and attractiveness of consumers. The contribution of the industrial sector as 2000 to the date placed starting toward the formation of Gross Domestic Product (GDP). Essentially for the food and beverage industry, each year is one of the manufacturers that contribute highly to the formation of GDP (Table 1)

TABLE I

ANNUAL GDP DISTRIBUTION AT CURRENT PRICES (PERCENT)

\begin{tabular}{|c|c|c|c|c|}
\hline \multirow{2}{*}{ No. } & \multirow{2}{*}{ Lapangan Usaha } & \multicolumn{3}{|c|}{ Tahun } \\
\hline & & 2008 & 2012 & $2016 *$ \\
\hline 1. & $\begin{array}{l}\text { Agriculture, Animal Husbandry, } \\
\text { Forestry and Fisheries }\end{array}$ & 14,5 & 14,5 & 13,5 \\
\hline 2. & Mining and Quarrying & 10,9 & 11,8 & 7,2 \\
\hline \multirow[t]{7}{*}{3.} & Manufacture & 27,8 & 24,0 & 20,5 \\
\hline & a. Oil and Gas Industry & 4,8 & 3,1 & 2,3 \\
\hline & b. Non Oil and Gas Industry & 23,0 & 20,9 & 18,2 \\
\hline & 1) Food, Beverages and Tobacco & 7,0 & 7,6 & 6,9 \\
\hline & $\begin{array}{l}\text { 2) Fertilizers, chemicals and rubber } \\
\text { goods }\end{array}$ & 3,1 & 2,6 & 2,4 \\
\hline & $\begin{array}{l}\text { 3) Transport Equipment, Machinery } \\
\text { and Equipment }\end{array}$ & 6,7 & 5,7 & 2,2 \\
\hline & 4) Others & 6,2 & 5,0 & 7,6 \\
\hline 4. & Others & 46,8 & 49,7 & 58,9 \\
\hline \multicolumn{2}{|r|}{ Indonesia } & 100 & 100 & 100 \\
\hline
\end{tabular}

Source; BPS, 2017

Especially related to the food and beverage industry, this industry has an important role in economic growth in
Indonesia. Therefore, the sector is one of each number of sectors that are the Government's priority in encouraging industry as a driver of the national economy.

In 2012, the contribution of the national food and beverage industry reached $7.6 \%$. This figure is higher than the contribution of other non-oil and gas industries. Furthermore, in 2016 the contribution of the food and beverage industry reached $6.9 \%$. This figure is indeed smaller than in 2012. However, it is still higher than the contribution of other non-oil and gas industries

The weakening of the rupiah exchange rate is considered to be able to suppress the domestic food and beverage industry. Because the increase in the US dollar will affect several components that are often imported from abroad. In the recent past, the rupiah exchange rate against the dollar continues to depreciate

Fluctuating exchange rates can have an impact on the prices of imported goods, both customer and raw materials so that changes in exchange rates will cause changes in import prices that will affect the prices of domestic goods and services used by the public. Fluctuations in prices of goods and services utilized by customers are observed in the Consumer Price Index (CPI) and the Wholesale Price Index (WPI). CPI and WPI have often used measures of domestic price levels and the most inflation size.

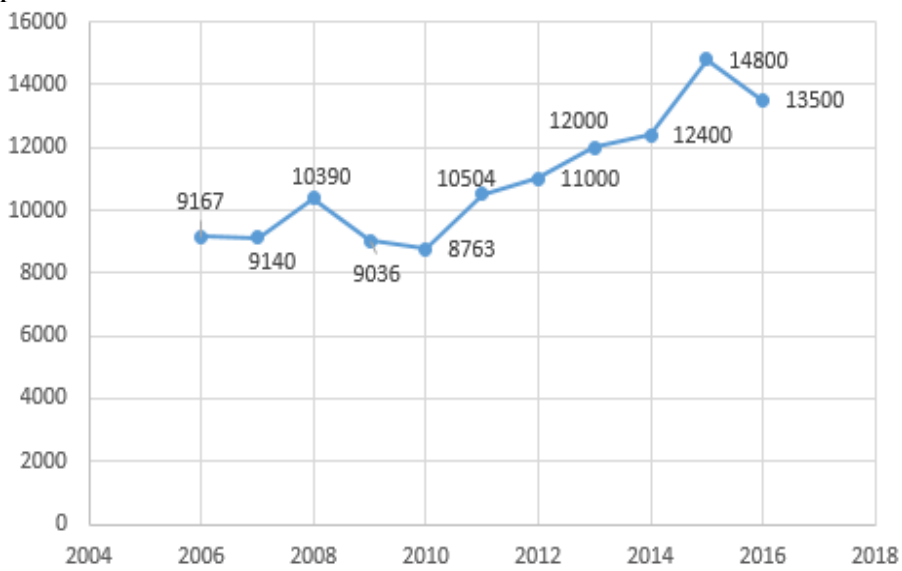

Fig. 1 Development of the rupiah exchange rate 
Changes in the exchange rate will affect the price of foodstuffs consumed by the public through the price of imported foodstuffs. Domestic price fluctuations that occur due to exchange rate fluctuations can trigger economic, social and political instability. Continuous price increases will also lead to an increase in inflation and affect the affordability of people's buying potential for food products because it will lead to more difficult access to food for the community, especially middle and low income, most of which are used for food consumption. If this is the case, then changes in exchange rates affect the food and beverage industry, because an increase in the exchange rate can affect the large trade price index in food groups and affect the consumer price index.

This research focused on knowing how the exchange rate changes affect the consumer price index and the producer price index in the food and beverage industry in Indonesia.

\section{LITERATURE REVIEW}

Exchange rate (ER) is defined as the price of foreign currency in units of domestic currency prices [1]. The exchange rate is also defined as the price of a currency of a country that is measured or expressed in another currency [2]. In the current free-floating exchange rate system, the central bank gives the exchange rate to adapt to equalize its value on the market. In other words, the exchange rate is created through a purely market mechanism, this is, the same as the value of any commodity, where the exchange rate is formed through a meeting between the forces of supply and demand in the market.

In a floating rate system, the exchange rate is determined directly by market forces and is liable to fluctuate continually, as dictated by changing market condition [3]. A freely flexible (or free-floating) exchange rate system exists whenever exchange rates (currency price) are freely determined by the demand and supply of currency by private parties. This system assumes the absence of any systematic government intervention in the foreign exchange market. The exchange rate moves freely in response to market forces [4].

Study into the effects of exchange rates on influencing prices and economic activity can refer to the results of previous research, including research results in the Australian Reserve Bank which examines the influence of changes in exchange rates on consumer prices. One of some results of his research on the impact of changes in exchange rates on inflation rates in Australia uses the markup pricing model, where the cost of output is determined by input prices. An analysis shows that the pressure on import costs was more important in 1980 than in the 1970s [5].

Then, to clarify how the effect of changes in exchange rates on domestic prices of imported consumer goods, can be identified in the process of two different adjustment stages. First, changes in the exchange rate are forwarded to changes in import prices. Second, this price, in turn, is passed to the final import retail price [6]. The effect of changes in exchange rates on consumer prices is stronger for consumer goods produced and containing imported raw materials or exposed to import competition so that their prices have a high level of joint movement with the exchange rate [7].

The results of empirical studies [8] then clarify [6] by obtaining empirical evidence about the effect of exchange rates past consumer prices in Australia during the inflation targeting period. He found that the effect of exchange rates past consumer prices was relatively low at the aggregate level but faster and greater for the prices of manufactured goods, which were often imported. There is some evidence that over the past decade, exchange rate movements have occurred flowing more quickly to retail prices for heavily traded goods. Research on exchange rates in influencing prices is also believed in studies conducted by [9] who study the effect of the nominal RMB exchange rate on consumer prices.

\section{DATA AND METHOD}

The data used in this study is secondary data in the form of time series. Import prices are measured by the wholesale price index (WPI), consumer food prices are measured by the CPI of food items obtained from BPS Jakarta, while the rupiah exchange rate against the US dollar is obtained of the Indonesia Economic and Financial Statistics of Bank Indonesia. The data used is annual statistical data for the period 2006 to 2016.

The effect of exchange rate changes on each food ingredient CPI will be examined using regression analysis. CPI data is adjusted using 2012 base year $=100$. Meanwhile, CPI data, four food ingredients groups are seasonality adjustment. Data is divided into exogenous variables (Rupiah exchange rate against USD) and endogenous (import trade price index, WPI import, CPI, and WPI index respectively).

The method used in this study is an empirical study hypothesis study, which tests the hypothesis of empirical studies that have been done and explains these findings, both consistent and inconsistent from the results of empirical findings, especially those relating to exchange rates, CPI, import WPI and WPI of each sector in Indonesia.

The hypothesis used in this study is that the exchange rate has a positive effect on CPI, WPI imports and WPI of each sector. The research model used to test hypotheses is:

$\mathrm{CPI}_{\mathrm{t}}=\beta_{0}+\beta_{1} \mathrm{ER}_{\mathrm{t}}+\varepsilon_{\mathrm{t}}$

$\mathrm{WPI}_{\mathrm{it}}=\alpha_{0}+\alpha_{1} \mathrm{ER}_{\mathrm{t}}+\varepsilon_{\mathrm{i} 2}$

Wherever; CPI is the Consumer Price Index, WPI is the Producer Price Index, ER is the exchange rate, $i=$ the food and beverage subsector. 


\section{RESULTS}

Based on the results of testing using the SPSS 22.0 Program on the research model, it was found that ER had a positive and significant sign on CPI, WPI imprint and WPI of each sector at alpha $1 \%$, with adjusted R2 values between $66 \%$ - 88\%, namely:

TABLE 2

THE RESULTS OF PARTIAL REGRESSION CALCULATIONS ON THE RESEARCH MODEL

\begin{tabular}{|l|r|r|r|l|}
\hline \multicolumn{1}{|c|}{ Variable } & Constant & Koefisien & tstat. & Adj. R \\
\hline $\begin{array}{l}\text { The Wholesale Price Indices of food } \\
\text { industry }\end{array}$ & 10.3849 & 0.0094 & 6.1733 & 0.7877 \\
\hline $\begin{array}{l}\text { Industry of processed and } \\
\text { preserved meat, fish and food oil }\end{array}$ & -10.0031 & 0.0119 & 4.7558 & 0.6837 \\
\hline Industry of milk and dairy products & 24.0181 & 0.0078 & 5.3239 & 0.7322 \\
\hline $\begin{array}{l}\text { Industry of ground grains and nuts } \\
\text { and fodder }\end{array}$ & -4.4945 & 0.0108 & 8.9835 & 0.8885 \\
\hline Other Food Industries & 32.0339 & 0.0073 & 5.7883 & 0.7647 \\
\hline Consumer Price Index, Foodstuff & -30.8835 & 0.0118 & 5.8867 & 0.7709 \\
\hline
\end{tabular}

Source: SPSS 22.00 Calculation Results

In general, the estimation of the effect of the exchange rate (ER) on CPI, WPI and WPI of each food sub-sector in Indonesia has a positive influence. In all models, the exogenous variable, ER, shows a positive sign of influence, while shown in Table 2 before. Each adjusted R2 value of each capital presents a number that ranges between $66 \%-88 \%$. This figure indicates that the variation in changes in the dependent variable can be explained above $66 \%$ by variations in changes in exogenous variables for all regression models.

One of the results of this study is the positive effect of exchange rates on CPI in Indonesia. This means that the greater the depreciation of the rupiah exchange rate, that will affect the increase in consumer prices shown by the raised CPI value. These results of the study are more supportive of empirical studies of [5], [6], [7], [8] and [9], that changes in exchange rates will affect prices.

Other findings from this study are the positive and significant effect of the exchange rate (ER) on imported WPI. These results indicate that the depreciation of the rupiah has encouraged an increase in the import WPI and conversely the appreciation of the exchange rate will reduce the import WPI value. The same thing happens to the WPI of each subsector, where the exchange rate coefficient has a positive sign on the regression model of each sub-sector. Thus, exchange rate depreciation has a significant impact on the increase in WPI both on \& nbsp; Industry of processed and preserved meat, fish and food oil; Industry of milk and dairy products; Industry of ground grains and nuts and fodder, as well as other food industries.

\section{CONCLUSIONS AND RECOMMENDATIONS}

Based on the results of the analysis and discussion of the research theme, conclusions can be drawn, namely; First, the exchange rate has a positive and significant influence on the CPI in Indonesia. Second, the exchange rate more has a positive and significant influence on imported WPI in
Indonesia. Third, the exchange rate also has a positive and significant influence on each of the WPI food and beverage industry sub-sectors in Indonesia. Thus, any weakening of the rupiah will have an impact on the increase in the value of CPI, WPI Imports, and WPI for each food and beverage industry sub-sector.

Based on this, the Government needs to continue to seek and maintain the rupiah exchange rate in a reasonable position. The weakening rupiah exchange rate could have an adverse impact on the value of the CPI, import WPI and the WPI of the food and beverage industry sub-sector, which will have an impact on inflation and the decline in the competitiveness of food and beverage products as a result of the higher prices of these commodities.

\section{REFERENCES}

[1] Salvatore, Dominick, “International Economic, ” Prentice Hall, Inc., New Jersey, 1997.

[2] Krugman, Paul R., and Maurice Obsfeld, "The International Economic, Theory and Policy," Addison-Wesley Publishing Company, 2001.

[3] McGregor, Lanchlan, 2000, "Economic Implications of Floating Exchange Rate", Journal of Economic, August 2000, Australia Monash University, pp. 1-15.

[4] Batiz, Francisco L. Rivera, and Luiz A. Rivera-Batiz, "International Finance and Open Economy Macroeconomics," Macmillan Publishing Company, New York, 1994

[5] Dwyer J, and R. Lam, "Explaining Import Price Inflation: A Recent History of Second Stage Pass-through,” RBA Research Discussion Paper, Number 9407, 1994.

[6] Dwyer J, and K. Leong, "Changes in the Determinants of Inflation in Australia," RBA Research Discussion Paper Number 2001-02, 2001.

[7] Norman D., and A. Richards, "Modelling Inflation in Australia", RBA Research Discussion Paper Number 2010-03, 2010.

[8] Elaine Chung, Marion Kohler and Christine Lewis, "The Exchange Rate and Consumer Prices," Bulletin, September Quarter, Reserve Bank of Australia, 2011, pp. $9-16$.

[9] Jun Liu, "A Study on the Relationship between Exchange Rate and Consumer Prices Based on ECM, The Open Cybernetics \& Systemics Journal, 2015, Vol. 9, pp. 1300-1306. 